\title{
THE IDEA OF MUSIC IN "OUT OFTHE CRADLE ENDLESSLY ROCKING"
}

\author{
WILLIAM F. MAYHAN
}

When Walt Whitman first published "Out of the Cradle Endlessly Rocking" (then called "A Child's Reminiscence") in the Christmas Eve 1859 edition of the New York Saturday Press, he described the poem as "a curious warble." He went on to observe that "the purport of this wild and plaintive song, well-enveloped, and eluding definition, is positive and unquestionable, like the effect of music. The piece will bear reading many times-perhaps, indeed, only comes forth, as from recesses, by many repetitions." ${ }^{1}$ Later, when defending the poem against a published attack charging it with meaninglessness, Whitman explained that his organizational strategy "was strictly the method of the Italian Opera."2 By linking his poem so closely and specifically to music, Whitman offers a vital clue not only to the poem's unorthodox structure, but also to its meaning. It seems odd, indeed, that so blatant a clue has for so long been largely overlooked. Although Robert Faner, of course, has written extensively on Whitman's general indebtedness to Italian Opera, his remarks concerning "Out of the Cradle" remain basically observations about recitative/aria structure and the sound patterns Whitman employs to equate birdsong with opera aria. ${ }^{3}$ Calvin Brown, in his book on the relationship between music and literature, does not limit himself to a discussion of sound patterns but focuses on the large organizational structures Whitman uses and shows how these structures are musical in nature. ${ }^{4}$ Brown's evidence for his thesis, however, rests on a close reading not of "Out of the Cradle," but "When Lilacs Last in the Dooryard Bloom'd." Charmenz Lenhart devotes a chapter in his Musical Influence on American Poetry to Whitman's use of musical methods to order and present poetic "themes," but discusses "Out of the Cradle" only in passing. ${ }^{5}$

The particular need for an investigation of the musical aspects of this specific poem, I believe, stems from the fact that in it, music plays not only a structural role, but also a symbolic one. In "Out of the Cradle Endlessly Rocking," Whitman blends his experience of music (as heard) with his philosophical conceptions of the nature and meaning of music in a marriage of matter and form that is itself the essence of music. This investigation will involve three major steps: an outline of Whitman's general attitude towards music, its nature and its communicative possi- 
bilities; a suggestion of possible sources for these attitudes; and finally, an investigation of how Whitman's conception of music relates to both the structure and meaning of "Out of the Cradle Endlessly Rocking."

During the late 1840 s and throughout the 1850 s, Whitman was an active concert- and opera-goer. ${ }^{6}$ His position as a reporter for the Brooklyn Daily Eagle allowed him many chances to put his musical experiences and reactions into print. Since he was not schooled in the technical aspects of music theory, Whitman's reviews of musical events focused mainly on purely personal reactions. This selection from an 1851 "Letter from Paumanok" is indicative of the kind of free-wheeling, impressionistic response Whitman had to musical performance:

Have you not, in like manner, while listening to the well-played music of some band like Maretzek's, felt an overwhelming desire for measureless sound-a sublime orchestra of myriad orchestras - a colossal volume of harmony, in which the thunder might roll in its proper place; and above it, the vast, pure Tenor,-identity of the Creative Power itself-rising through the universe, until the boundless and unspeakable capacities of that mystery, the human soul, should be filled to the uttermost, and the problem of human cravingness be satisfied and destroyed?

Of this sort are the promptings of good music upon me. ${ }^{7}$

This response in many ways embodies the kind of attitude Whitman would hold toward music throughout his life: the poet almost always connects his experiences of music to an intuitive experience of the innermost realm of human nature. Music becomes the symbol for a kind of deep, universal order, an order which alone can fill the "boundless and unspeakable capacities" of the human soul. As music criticism, of course, this is woefully subjective and inadequate (although rather typical of nineteenth century responses to music); but as an indication of the kind of meaning Whitman ascribed to music, it is telling indeed. Music (and ultimately only music) holds the solution to the enigma of man in the world; it alone can "satisfy" and "destroy" the separateness man inevitably feels in the face of the otherness of the world-and can replace this feeling of separateness with a "colossal volume of harmony."

That this mystical reaction to the power of music remains terribly abstract is for Whitman an inevitable consequence of the nature of musical language itself. Music communicates directly that which words can only obliquely describe. In a review of a performance of $L a$ Favorita published in the Eagle, Whitman recreates his own struggle to understand how music means. He tries to ascribe specific meanings to the tenor's last-act aria, but ultimately must resort to a simple "Listen," as the sounds themselves (always imaged in oceanic terms) communicate a meaning beyond the realm of word: 
The strains of death, too, come plaintively from his lips. Never before did you hear such wonderful gushing sorrow, poured forth like ebbing blood, from a murdered heart. Is it for peace he prays with that appealing passion? Is it the story of his own sad wreck he utters?

Listen. Pure and vast, that voice now rises, as on clouds, to the heavens where it claims audience. Now, firm and unbroken, it spreads like an ocean around us. Oh, welcome that I know not the mere language of the earthly words in which the melody is embodied; as all words are mean before the language of true music. ${ }^{8}$

The poet confesses that he is glad he cannot understand the words the tenor sings-since the whole meaning is more truly expressed in the music itself. The questions he posits and then rejects ("Is it for peace he prays with that appealing passion? Is it the story of his own sad wreck he utters?") are an attempt to give specific meanings to a language whose only referent is general and universal. The poet will have the same problem in "Out of the Cradle." Although he will "translate" the melody of the mockingbird's song, the specific meanings will leave the poet unsatisfied. Only a "clew" whispered from the sea will ultimately enable the poet to reach a purely musical understanding of the bird's song of love and desire.

Although Whitman's chances of hearing music and opera dwindled during the war years and practically disappeared after his decline in health, the musical understanding he experienced during his New York days remained. He admits as much in his conversations with Horace Traubel, recorded later in his life:

My younger life was so saturated with the emotions, raptures, up-lifts, of such musical experiences that it would be surprising if all my future work had not been colored by them. A real musician running through Leaves of Grass - a philosopher musician - could put his finger on this and that anywhere in the text no doubt as indicating the activity and influences I have spoken of. ${ }^{9}$

The phrase "philosopher musician" can help us further delineate just what kind of influence musical experience had on Whitman. Because he remained relatively unsophisticated about the technical aspects of music, any structural and organizational influence music would have on the poet must concern large, easily felt musical forms. (The basically unsubtle emotional and architectural effects of the kind of Italian grand opera then popular are the kinds of "gross" effects we can trace in the structure of the poems, and we should not expect any minute adherence to more intricate musical structures such as sonata form, etc.) But together with the felt structural principles of musical organization, the poet's conception of the "philosophy" of music also plays an important role in the poetry. Music assumes a symbolic import as well as a structural one. Whitman's conception of music as a kind of universal language of ultimate reality and deepest subjectivity becomes a force behind the meaning of the poems as well as behind their structure. In 
"Out of the Cradle," as we shall see, this symbolic function of music as idea and metaphor plays an especially strategic role in the poem's resolution.

Just what does music symbolize for Whitman? A glance at a few of his other poems will perhaps be helpful here. Music is a constant allusion throughout the poetry (that there are so many "Songs" in Leaves of Grass is not merely an idle affectation on the author's part, but an indication of Whitman's real desire to have readers think of his poetry as a kind of music). Section 26 of "Song of Myself" (which begins "Now I will do nothing but listen"), after cataloging the sounds of the poet's experience as if they were palpable and visible things, repeats the imagery of the "Creative Power" of the tenor voice we have already witnessed in Whitman's "Letter to Paumanok":

I hear the chorus, it is a grand opera,

Ah this indeed is music - this suits me.

A tenor large and fresh as the creation fills me,

The orbic flex of his mouth is pouring and filling me full. ${ }^{10}$

Music, we can see here, is conceived of, very abstractly, as that which fills a void - a void which is, significantly, the "me" of the poet himself. This will not be the only time Whitman will connect music with his own deepest subjectivity. The sexual implications of music's creative act are also implicit in these lines. Music represents the power of the life-force itself - a perceptible (audible) manifestation of that élan vital which is itself its own meaning. Here we see Whitman again connecting the reality of music with the problem of desire, of "human cravingness." The passage continues:

I hear the train'd soprano (what work with hers is this?)

The orchestra whirls me wider than Uranus flies,

It wrenches such ardors from me I did not know I possess'd them,

It sails me, I dab with bare feet, they are lick'd by the indolent waves,

I am cut by bitter and angry hail, I lose my breath,

Steep'd amid honey'd morphine, my windpipe throttled in fakes of death,

At length let up again to feel the puzzle of puzzles,

And that we call Being. $(L G, 56)$

Trying desperately to provide this music with adequate images, Whitman traverses not only the earth, but all the cosmos as well. Almost hysterically, Whitman searches for those words which can convey the mysterious sense of meaning that pure music asserts. But the music so completely overwhelms and overpowers the poet that his merely verbal imagination is strained almost to the breaking point ("my windpipe throttled in fakes of death"). The phrase he finally resorts to- "puzzle of puzzles"-by its use of the same word in an almost tautological com- 
bination, represents a kind of exhausted verbal capitulation in the face of music's mystery. The final word, significantly enough, is one from philosophy: Being. Music, Whitman here says, is the only means available to adequately symbolize the mystery of being. Music, in other words, symbolizes directly that ultimate ontological mystery which words can only approach obliquely.

Another poem, "That Music Always Round Me," written in the same year as "Out of the Cradle," also focuses on the basically ontological nature of the musical symbol. Reading this poem in light of our previous discussion will reveal a remarkable consistency in both the verbal imagery used to describe music, and the mysterious meaning ascribed to it:

That music always round me, unceasing, unbeginning, yet long untaught I did not hear,

But now the chorus I hear and am elated,

A tenor, strong, ascending with power and health, with glad notes of daybreak I hear,

A soprano at intervals sailing buoyantly over the tops of immense waves,

A transparent base shuddering lusciously under and through the universe,

The triumphant tutti, the funeral wailings with sweet flutes and violins, all these I fill myself with,

I hear not the volumes of sound merely, I am moved by the exquisite meanings,

I listen to the different voices winding in and out, striving, contending with fiery vehemence to excel each other in emotion;

I do not think the performers know themselves-but now I think I begin to know them. $(L G, 449)$

Music, Whitman here asserts, has "well-enveloped" him all the timeonly he never heard it. Employing the same oceanic and cosmic imagery we have seen before, Whitman creates a feeling in the reader that music is almost as pervasive and vital as the air we breathe. This music contains all: birth ("glad notes of daybreak") and death ("funeral wailings with sweet flutes and violins"). But to hear the music does not automatically mean its auditors will understand. One must learn first to hear ("long untaught I did not hear"); then one must learn to understand ("I hear not the volumes of sound merely, I am moved by the exquisite meanings"). It is the function of the poet to "know" these "exquisite meanings" - and to try to teach others both to hear and understand. The speaker of this poem, like the speaker in "Out of the Cradle," has come to understand the meaning of music (the mystery of being); but unlike his counterpart, he does not try to communicate the newly discovered meaning to his readers. In this poem, the speaker seems more tentative; he knows the significance of his enveloping music, but he is only "beginning to know." In "Out of the Cradle," the poet will share his experience with his auditors. 
One final look at Whitman's use of the idea of music in his poetry, using a piece written about eight years after "Out of the Cradle," will reinforce our understanding of how the poet employs music as a symbol. "Proud Music of the Storm," basically an expansion of the mood and imagery found in Section 26 of "Song of Myself," is structured as a kind of elaborate dream vision, only this "vision" consists of sounds, not images. All the world and its people are imagined in sound; all corners of the globe are represented in this vast catalog of the music of humanity. And Whitman not only lists music of men, but also includes "The rain, the growing corn ... / The measur'd sea-surf beating on the sand" and other sounds of nature. Heard with the special ear of the poet, in other words, the random noise of everyday life can be perceived as having a kind of order, a deep reason and structure which is concealed from ordinary perception. It is this deep structure which music can symbolize directly, and it is this deep sense of order and meaning which Whitman wishes to communicate both structurally and symbolically. After completing this great compendium of musicians and composers, Whitman includes himself among their number:

Composers! mighty maestros!

And you, sweet singers of old lands, soprani, tenori, bassi!

To you a new bard caroling in the West,

Obeisant sends his love. $(L G, 409)$

He presents himself as "a new bard," a musician/poet who does not merely say, but sings ("caroling in the West"). The kind of direct symbolization of inner order which music attains, then, is the kind of effect Whitman wishes his poetry to achieve. When he awakes from his musical dream and recalls what he has heard ("the voices of the universe"), the poet realizes exactly what his poetry must also strive to attain:

And questioning all those reminiscences, the tempest in its fury,

And all the songs of sopranos and tenors,

And those rapt oriental dances of religious fervor,

And the sweet varied instruments, and the diapason of organs,

And all the artless plaints of love and grief and death,

I said to my silent curious soul out of the bed of the slumber-chamber,

Come, for I have found the clew I sought so long,

Let us go forth refresh'd amid the day,

Cheerfully tallying life, walking the world, the real,

Nourish'd henceforth by our celestial dream. ( $L G, 409-410)$

The ultimately musical nature of reality provides Whitman with the "clew" he needs to be able to "go forth refresh'd" and confront "the real." By being reinforced with a sense of the deep, underlying interrelatedness of things (an interrelatedness that can be symbolized best in 
musical terms), the poet can confront the intractable world of the real (a world of disparates and seeming disorder) with confidence. He will be able to compile his vast catalogs of "things" without fear of succumbing to the horror of their apparent eternal separateness and disunity, for the poet has the "clew" which unifies and harmonizes. This "clew," moreover, while suggested by heard music, receives a final authentication when it is found to match the sweeter unheard melody of the poet's own "rhythmus." The deep structure of the world somehow matches the inner structure of the poet's own psyche-and the harmony of the two gives the poet the confidence he needs to "go forth in the bold day and write."

Whitman's almost mystical intuitions about the nature and meaning of musical utterance were not unique in the nineteenth century. Many influential thinkers in America and abroad, including two who can be directly linked to Whitman's early years, find music to be the most mysterious and profound of the arts. Thomas Carlyle, for example, who had a considerable influence on Whitman, ${ }^{11}$ investigates the relationship between music and poetry in his book On Heroes, HeroWorship, and the Heroic in History. When Whitman read the book (and we're certain he did since he reviewed it for the Eagle), here are just a few of the ideas he encountered there:

A musical thought is one spoken by a mind that has penetrated into the inmost heart of a thing; detected the inmost mystery of it, namely the melody that lies hidden in it; the inward harmony of coherence which is its soul. . . . The meaning of Song goes deep. Who is there that, in logical words, can express the effect music has on us? A kind of inarticulate unfathomable speech, which leads us to the edge of the Infinite, and lets us for moments gaze into that! . . . All deep things are Song. It seems somehow the very central essence of us, Song; as if all the rest were but wrappages and hulls! The primal element of us; of us, and of all things. . . . See deep enough, and you see musically; the heart of Nature being everywhere music, if you can only reach it. . . . Go deep enough, there is music everywhere. A true inward symmetry, what one calls an architectural harmony. . . . (109, 119) ${ }^{12}$

We can see here the same kind of correlation between the realm of music and a mysterious deep level of order and meaning as we find in Whitman's thought. The meaning of music cannot be translated into words (it must remain, in essence, "inarticulate" and "unfathomable"); it must be experienced on an intuitive level. Carlyle does not investigate music as actual phenomenal sound, but plunges immediately deeper into a discussion of the idea of music, into questions of what music symbolizes. What he finds it does symbolize is "an inward harmony of coherence," a harmony that underlies the confusing disparateness of the world of objects and things. How similar these thoughts are to those of Whitman. The influence is unmistakable and striking. 
But perhaps the influence of another thinker, this one American and closer to home, is even more relevant. In his essay, "The Poet," Emerson regards the task of the poet to be primarily a musical one:

... whenever we are so finely organized that we can penetrate into that region where the air is music, we hear those primal warblings, and attempt to write them down, but we lose ever and anon a word, or a verse, and substitute something of our own, and thus miswrite the poem. The men of more delicate ear write down these cadences more faithfully, and these transcripts, though imperfect, become the songs of the nations. ${ }^{13}$

Like Carlyle, Emerson asserts that music somehow precedes or underlies the phenomenal world of things (it is "primal"). And the poet is that man who can penetrate past the quotidian realm of accident and appearance - to the rarified air of pure essence ("where the air is music"). This passage of Emerson's is especially relevant to our discussion of "Out of the Cradle" because it reads almost as a creative recipe for Whitman's poem. Not only does Whitman refer to his poem as "a curious warble," he also structures the poem as a kind of dramatic reenactment of this Emersonian penetration into the mysterious but vital realm of pure (musical) essence.

As we have already noted at the very beginning of our discussion, Whitman himself admitted that he was striving for the "effect of music" when he wrote "Out of the Cradle Endlessly Rocking." That this musical effect will remain utterly beyond "definition" is the first important effect we should note. The meaning of Whitman's poem, like the meaning of Fernando's last-act aria in La Favorita, cannot be communicated in any other way than through its own form. Its meaning will be evident, almost self-evident ("positive and unquestionable"), but the meaning must remain a felt meaning: an immediate conviction, powerful and intuitive, but utterly beyond paraphrase or epitome. ${ }^{14}$ This "immediate conviction" of meaning, moreover, will emerge "as from recesses." These "recesses," as we have seen from the ending of "Proud Music of the Storm," will be those deepest parts of our own psyches: the meaning will emerge as from inside the auditor, and will carry the same conviction as a direct experience of self. ${ }^{15}$ After repeated hearings, then, the "purport" of Whitman's "curious warble" will "come forth" from the hearer's own soul. He will be able to feel and understand the poet's experience of world harmony because his own deepest psychic make-up shares this structure. Music, for Whitman (and for Emerson and Carlyle as well), is a direct symbolization of the deepest realm of Being-and since this "primal" ground of being is shared by poet/musician, reader/ auditor, and the world itself, music will expose and make perceptible that reality which is the essence of both self and other. An experience of this kind, as we have sensed from Whitman's own description of his reaction to music, is an almost mystical (but immediate) conviction of 
the essential unity of all creation.

That music communicates these feelings of world harmony and order for Whitman we can have no doubt; the evidence is in the poetry and reviews discussed earlier. How this essentially musical symbolization can be transferred to the realm of word, however, remains to be seen. Whitman is a poet, not a musician. Any attempt to create musical meaning out of pure sounds of the words, he understands, would be misdirected: it would deny the very essence of word (as sign). The challenge for Whitman is to use words as words, their meanings as well as their sounds, in a musical way. But precisely what is a musical way? Susanne Langer, who shares Whitman's conviction that music does have meaning, and that it symbolizes deep (if very abstract) realms of human experience, can offer some help here. In her seminal work, Philosophy in a Nerw Key, she discusses the essential nature of how music works as symbol. "The fundamental relationships in music," she points out, "are tensions and resolutions; and the patterns generated by these functions are the patterns exemplified in all art, and also in all emotive responses. Whenever sheer contrasts of ideas produce a reaction, whenever experiences of pure form produce mental tensions, we have the essence of melody." 16

Whitman must, then, if he is to act in a musical manner, produce tensions and then resolve them. But these tensions, if they are to be musically experienced, must be "experiences of pure form," and this presents a considerable problem for the poet. Words have meanings, meanings which are separate from the word's "pure form" (sound). How can the poet create the illusion (and that is what it must be, a kind of sleight-of-hand) of "pure form" in the words he uses? The answer, I believe, is in his choice of words and the context he creates for these words. Although the most important words Whitman chooses to employ in "Out of the Cradle" (bird, boy, moon, sea, song) certainly have fixed denotations, these denotations remain very general ones. Whitman doesn't supply any individualizing detail to separate this bird from any other bird, or this boy from any other boy. The reader feels that although the words signify things, these things remain, in a very real sense, abstractions. Whitman does not deny meaning and create tension from pure sound; he manipulates the abstract meanings in a musical way. The abstract, symbolic, almost archetypal meanings of the words Whitman selects for this poem are as far from narrow, denotative meanings as they can be. The symbolic function of these words possesses the same kind of abstractness and variability as musical themes.

What is it about Whitman's abstract (yet specific) images in "Out of the Cradle" that reminds us of musical themes? Langer can again provide some assistance here, with her investigation of those properties which characterize a suitable musical idea: 
... musical forms have certain properties to recommend them for symbolic use: they are composed of many separable items, easily produced, and easily combined in a great variety of ways; in themselves they play no important practical role which would overshadow their semantic function; they are readily distinguished, remembered, and repeated; and finally, they have a remarkable tendency to modify each other's characters in combination. . . . ${ }^{17}$

We can see immediately that all of Whitman's images in "Out of the Cradle" qualify eminently for use as themes: they are basically neutral by themselves; they can be easily distinguished, remembered, and repeated; but, most important, they are chosen because of their capacity to be combined. The boy can have a poetic relationship with the bird, with the sea, with the song; likewise, the sea can be put in structural juxtaposition with the moon, and together they can be observed by both the boy and the bird. And each of these juxtapositions (almost infinite in variety, like music) can play a role in modifying the feeling or meaning that the poet has in mind. Each of these combinations, in addition, can be distinguished, remembered, repeated, and combined. Layer upon layer of meaning begins to accumulate until, at the end, as we shall see, the effects of infinite interrelatedness (harmony) will affect not only the poem's structure, but will be, in itself, an embodiment of its meaning.

Whitman reinforces our experience of his images as musical themes by using them as such in a context clearly modeled on an established musical genre - in this case, opera. Notice in these opening lines of "Out of the Cradle," for example, how the poet presents his images swiftly, without explanation or any real sense of verbal logic. We experience the bird, the child, the moon, the song, without any indication of how these images relate (or ultimately will relate) to one another:

Out of the cradle endlessly rocking,

Out of the mocking-bird's throat, the musical shuttle,

Out of the Ninth-month midnight,

Over the sterile sands and the fields beyond, where the child leaving his bed wander'd alone, bareheaded, barefoot,

Down from the shower'd halo,

Up from the mystic play of shadows twining and twisting as if they were alive,

Out from the patches of briers and blackberries,

From the memories of the bird that chanted to me,

From your memories sad brother, from the fitful risings and fallings I heard,

From under that yellow half-moon late-risen and swollen as if with tears,

From those beginning notes of yearning and love there in the mist,

From the thousand responses of my heart never to cease,

From the myriad thence-arous'd words,

From the word stronger and more delicious than any,

From such as now they start the scene revisiting,

As a flock, twittering, rising, or overhead passing,

Borne hither, ere all eludes me, hurriedly,

A man, yet by these tears a little boy again,

Throwing myself on the sand, confronting the waves, 
I, chanter of pains and joys, uniter of here and hereafter,

Taking all hints to use them, but swiftly leaping beyond them,

A reminiscence sing. ( $L G, 246-247)$

I have quoted this first section in its entirety because it is only in its entirety that it can be adequately addressed. Viewing it apart from what follows, moreover, will help us to understand, to some extent, the utter confusion registered by some of its first readers. The confusion is not the same kind of immediate disorientation which sometimes occurs when an author begins his story in medias res. That kind of confusion is usually quickly resolved as the story unfolds logically. The disorientation in this opening section of "Out of the Cradle" is only resolved after the entire poem has been experienced. In fact, only after the reader has concluded the poem is he able to go back and realize the purpose of this opening section: it has been an overture. In many operatic overtures, especially those of the early nineteenth-century Italian school, the melodic material forms a kind of potpourri of the upcoming opera's best "tunes." The audience is given both the flavor of the work and a miniature, suggestive pre-enactment of the drama which is about to begin. This is exactly the case with Whitman's introduction. Image after image is presented in the most loosely organized way. The minimal syntactic cohesion is provided by a long series of prepositions: "Out . . Out . . . Out . . . Over . . . Down . . U Up . . . Out . . . From . . ..” The kind of movement generated by these directional prepositions reinforces Whitman's symbolic use of his themes: any actual physical or realistic visualization of these images is prevented from the start. Whitman thereby forces his audience to read his words abstractly, to "hear" their meanings musically.

After the overture, Whitman proceeds to the pivotal event of the piece-a "scene with aria." The movement to scenic presentation entails an obvious change of style from that of the overture. Now the reader is able to visualize the situation in a kind of actual time ("When the lilac scent was in the air"). The curtain is up. After presenting the dramatic situation and a short duet of joy by the birds, Whitman abruptly ("Till of a sudden") has the female bird disappear as he prepares the audience for the male bird's long, lamenting aria. Much has been written about the stylistic differences between the speaker's voice - in recitative-and the male bird's song, an aria. ${ }^{18}$ Whitman certainly switches to a much more lyric vein with his "translation" of the bird's song. He repeats words often, for example, from the "Soothe! soothe! soothe!" of the aria's first line to the final despairing cry of "Loved! loved! loved! loved! loved!" This mere repetition of words blurs the boundaries between sound and meaning (if one repeats any word five times the sound pattern gradually begins to take precedence over the meaning). Repeated phrases at the end of lines are also common throughout this aria ("But 
my love soothes not me, not me"). This repetition of phrase gives the lines a song-like quality. The use of exclamation points is very common, underscoring the emotionally charged nature of the song. Whitman also prints the entire aria in italics, to separate it from the rest of the poem and distinguish it as song.

Although Whitman very cleverly makes his bird's lament sound musical, this section of the poem is actually not the most musically sophisticated. Whitman is most concerned here not with relating themes and images in a musical manner, but merely with differentiating the bird's song from the speaker's voice-in order to be able to use the song itself as a musical symbol later in the poem. Although the sounds are lovely enough, and the bird's impassioned pleas to the moon and sea certainly convey a great deal of poetic emotion, the poet's "translation" of the notes is basically still a somewhat superficial translation of sound pattern. It provides the outward meaning of the song (i.e., the bird has lost his love and is desperately lonely), but cannot instill this literal meaning with any wider significance. The situation, in other words, remains melodrama - the presentation of one particular episode of pathos. And that is why the poet (like the reader) remains basically unsatisfied after the bird completes his aria. This stage of the poem is analogous to that stage in Whitman's earlier "Letter from Paumanok" (his review of La Favorita) where he wonders about the meaning of Fernando's aria ("Is it for peace he prays with that appealing passion? Is it the story of his own sad wreck he utters?"). In that instance, we should remember, Whitman rejects these outward (melodramatic) answers to his questions about music's meaning - and plunges instead into the pure ocean of sound ("Listen") to find the real meaning in "the language of true music."

The "language of true music," that language which can reach beyond appearances to the essence beneath, begins to truly sound in "Out of the Cradle" only after the mockingbird's song has become an echo. Only when the despairing, self-conscious monody becomes a symbol itself and joins with Whitman's other "themes" will the poet be able to combine the seemingly dissonant facts of the phenomenal world into a harmonious unity. Real meaning, real significance, cannot be achieved while the poet focuses only on the painful lament of the desperate birdthis lamenting song must be interrelated both to the poet's inner psyche and to the realm of "objective" reality before a satisfactory harmony can be sounded. "Listen" to how Whitman juxtaposes various songs to create a complex harmony of meaning:

The aria sinking,

All else continuing, the stars shining,

The winds blowing, the notes of the bird continuous echoing, With angry moans the fierce old mother incessantly moaning, On the sands of Paumanok's shore gray and rustling, 
The yellow half-moon enlarged, sagging down, drooping, the face of the sea almost touching,

The boy ecstatic, with his bare feet the waves, with his hair the atmosphere dallying,

The love in the heart long pent, now loose, now at last tumultuously bursting,

The aria's meaning, the ears, the soul, swiftly depositing,

The strange tears down the cheeks coursing,

The colloquy there, the trio, each uttering,

The undertone, the savage old mother incessantly crying,

To the boy's soul's questions sullenly timing, some drown'd secret hissing,

To the outsetting bard. ( $L G, 251)$

Compared to the melodrama of the mockingbird's lament, this sophisticated blending of the image (theme) communicates a meaning only approachable through the language of true music. The bird's song, still "echoing," and the incessant "moans" of the pounding sea are both perceived - and blended - within the consciousness of the "ecstatic boy." With his feet in the "waves" and his head in the melody-filled "atmosphere," the boy simultaneously experiences both the inner world of subjectivity and the intractable presences of "outer" physical reality. Because he hears the music of both of these apparently irreconcilable realms of experience, the artist/boy is able to perceive their underlying structural similarities - and can therefore combine and unify them. The bird, the sea, and the boy are merged in a unity which Whitman can only describe in musical terms: "the trio." The seemingly eternal division, then, between self and other is resolved in a mystical combination which Whitman images musically. The "trio" represents a simultaneous maintenance and resolution of difference. And if man is not to despair in the face of his almost total alienation (the mockingbird's role as object in a senseless world of things), he needs symbols which allow him to perceive, if only for a moment, the essential unity beneath the surface division. The artist is the person who is able to conceive of the paradox of unity beneath difference and set it before his fellow creatures in symbolic form (the only way it can be perceived). Whitman is one of these artists ("Now in a moment I know what I am for") - and music is the symbol he feels embodies this life-saving paradox most perfectly.

And although Whitman allows us to share his vision of wholeness and unity through the symbol of music ("the trio"), he wants to do more: he wants to make us experience this unity as well. He wants us to be able to feel the deep structure of world order as well as intellectually conceive of it. The poet therefore asks the eternal sea for the word which will finally and completely explain everything to the poet and the reader. The sea responds:

Whereto answering, the sea,

Delaying not, hurrying not,

Whisper'd me through the night, and very plainly before daybreak, 
Lisp'd to me the low and delicious word death,

And again death, death, death, death,

Hissing melodious, neither like the bird nor like my arous'd child's heart,

But edging near as privately for me rustling at my feet,

Creeping thence steadily up to my ears and laving me softly all over,

Death, death, death, death, death. ( $L G, 252-253)$

As in all "true music," the form of the sea's response is, in large part, its content. And perhaps more than any other place in the poemeven more than in the "translation" of the mockingbird's aria-we sense the overwhelming nature of the sea's reply as sound. The longed-for word of explanation is whispered, lisped, and hissed. When the word finally does appear, its constant repetition reinforces Whitman's desire for us to relate to his word as a spoken one - almost a sung one. The final line of this section, the five-fold repetition of the word "death," is certainly the climax of the entire poem-and it affects the reader in a number of important ways. Of course the purely denotative meaning of the word plays a role in the line's effectiveness. To have the culminating answer to the question of human meaning and destiny to be a five-fold "death" seems at first almost overwhelmingly pessimistic. Whitman preempts this negative reader response, however, by prefacing his first mention of the word with the phrase "the low and delicious word." "Delicious" in this context must carry a good deal of weight: it must predispose the reader to react to the word "death" in an uncharacteristically positive way. (The word "delicious" also underscores the very intimate nature of one's response to death - taste is certainly the most intimate of the five senses.) But besides the purely denotative meaning of the word death, Whitman also employs musical means to color his reader's reaction to this climactic line. The five-fold repetition, first of all, will immediately remind the reader of the corresponding five-fold repetition in the mockingbird's despairing aria: "Loved! loved! loved! loved! loved!" Love and death, then, are mysteriously combined in the reader's mind along with the memory of song (the context of the bird's song as catalyst for this whole epiphany is still very vivid in the reader's mind).

The rocking motion of the spoken line also brings to mind a remembrance of the first lines of the entire poem and their image of a rocking cradle. So birth joins death, love, and song in a suggestive tour de force of poetic and musical harmony. If the reader has followed Whitman's direction and is open to the suggestiveness of the poet's abstract musical idiom, then this climactic line should have the same mysteriously potent effect as music (especially the kind of final tonic "resolution" which spells release from constant chromatic "tension"). The reader, of course, will not be able to say, in words, precisely what this important line "means"-any "explication" of music in words will inevitably be inadequate. But he will feel in some real sense the profound 
and eternal unity underlying bird, sea, boy/poet - and himself as well. If felt deeply enough ("musically"), this unity, moreover-a unity that must include both the joys of love and the pain of separation and death-will allow a momentary triumph over the chaotic randomness and meaninglessness which inevitably result from living in a world of disparate things, as we sense (wordlessly) the profound cohesion ("harmony") of all created reality into one, eternal, everchanging whole.

The solution ("clew") to the ultimate mystery of being is, for Whitman, an essentially musical solution. (The sea's final word, we should remember, is called "the key"- a term which again reinforces the basically musical nature of the experience of meaning.) To say "Out of the Cradle Endlessly Rocking" finally communicates only the pessimistic reality that all men are born to die would demand a reading of the sea's final word on a purely literal, denotative level. Whitman, however, exposes the poverty of such a literal attitude toward reality by presenting his readers with music as both symbol and experience. By doing so, he helps us understand, in a way we cannot name, what Carlyle meant when he said: "See deep enough, and you see musically."

\section{University of Missouri-St. Louis}

\section{NOTES}

1 As noted by Bradley and Blodgett, this description of the poem was included as an anonymous editorial notice of the poem in the same issue of the Saturday Press. See Leaves of Grass, Comprehensive Reader's Edition, ed. Harold W. Blodgett and Sculley Bradley (New York: New York University Press, 1965), 246-247n.

2 Included in an anonymous defense of the poem, printed in the Saturday Press (January 7, 1860). Reprinted in Out of the Cradle Endlessly Rocking: The Merrill Literary Casebook Series (Columbus: Charles E. Merrill Publishing Company, 1971), 26.

3 Robert D. Faner, Walt Whitman and Opera (Philadelphia: University of Pennsylvania Press, 1951).

4 Calvin S. Brown, Music and Literature: A Comparison of the Arts (Athens: University of Georgia Press, 1948).

5 Charmenz S. Lenhart, Musical Influence on American Poetry (Athens: University of Georgia Press, 1956).

6 Faner, 3-16.

7 Walt Whitman, The Uncollected Poetry and Prose of Walt Whitman, ed. Emory Holloway (London: William Heinemann, 1922), 1:256.

8 Whitman, Uncollected, 1:258-259.

9 Horace Traubel, With Walt Whitman in Camden (July 16, 1888-October 31, 1888) (New York: Rowman and Littlefield, 1961), 174.

10 Walt Whitman, Leaves of Grass, 56. All subsequent citations from Whitman's poetry come from the Blodgett and Bradley edition previously cited. 
11 For details on Carlyle's influence on Whitman, see Floyd Stovall, The Foreground of Leaves of Grass (Charlottesville: University Press of Virginia, 1974).

12 Thomas Carlyle, On Heroes, Hero-Worship and the Heroic in History (London: Oxford University Press, 1963).

13 Ralph Waldo Emerson, Essays and Lectures (New York: The Library of America, 1983), 449.

14 John T. Irwin, "Self-Evidence and Self-Reference: Nietzsche and Tragedy, Whitman and Opera," New Literary History 11 (1979), 182.

15 Irwin, 188.

16 Susanne Langer, Philosophy in a New Key (Cambridge: Harvard University Press, 1942), 227.

17 Langer, 228.

18 See Faner, 174-177. 